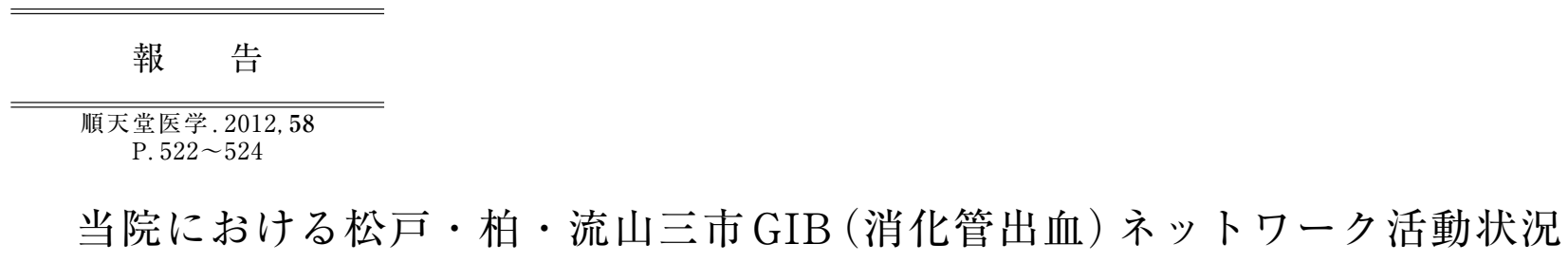

朝 蔭 直 樹*1) 諏 訪 達 志*1) 秋 山直*2)

千葉県松戸市, 柏市, 流山市の三市では 2010 年 3 月より急性吐・下血症例に対し, 夜間・休日において内視鏡による止血治療 を含む救急医療を行うため, 夜間・休日救急当番制度 (GIB ネットワーク) を運用している. 当院における 2010 年 3 月より 2012 年 2 月までの活動状況を報告する. 効果的にネットワークを維持するため, GIB 当番病院と二次救急当番病院, 救急隊の良好な コミュニケーションが重要であると思われた.

キーワード : GIB (Gastro Intestinal Bleeding), 内視鏡的治療, 救急医療, 夜間 ·休日救急当番制度

\section{緒言}

千葉県松戸市，柏市，流山市の三市に扔いて2010 年 3 月より, 急性吐・下血（消化管出血, Gastro Intestinal Bleeding；GIB）症例に対し，夜間・休日に おいて内視鏡による止血治療を含む救急医療を行うた め, 夜間・休日救急当番制度 (GIB ネットワーク)を 創設し運用している. 参加7 病院でスタートしたが随 時6病院が加わり, 現在は 13 病院が市民の消化管出 血救急医療に携わっている. 当院は内視鏡室スタッフ の協力の下, 日本消化器内視鏡学会指導医 3 名, 専門 医1名を含む内視鏡医 9 名の体制でネットワーク開始 時より今日まで活動している. 当院における2010年 3 月より 2012 年 2 月までの GIB ネットワーク活動状況 を報告する。

\section{松戸・柏・流山三市GIB ネットワークとは}

急性の吐血・下血症例に対し夜間・休日における 内視鏡による止血治療を含む救急医療を目的として, 2010 年 3 月に松戸，柏，流山三市医師会・消防機関が 協力し夜間・休日における市民のセイフティネットと して創設された，その設立背景には，当時松戸市立病 院の機能縮小に伴い松戸市内GIB症例に対する全日 輪番体制が不可能となり，GIBに対し早急なセイフ ティネットの構築が望まれていたこと, 松戸市には当 ネットワークのモデルとなったCCU (Coronary Care Unit）ネットワークが運用されていたことなどによ り, 松戸市医師会が中心となって運用が開始された. ネットワーク参加病院の条件として, (1)内視鏡による 緊急止血治療体制を整備している，(2)稼働対象時間带 は平日：17：00〜翌 $9: 00$, 土曜 : $13: 00$ 翌 $9: 00$,

* 1) 柏厚生総合病院外科

*2) 柏厚生総合病院内科

〔July 28, 2012 原稿受領〕〔Aug. 6, 2012 掲載決定〕
休日：9：00〜翌 9：00, (3)入院可能ベッドを 1〜2床 用意することとし，2010年 3 月発足時は当院を含め 7 病院であったが, 現在の参加病院は松戸市 : 松戸市立 病院, 千葉西総合病院, 新松戸中央総合病院, 新東京 病院, 五香病院, 柏市: 柏市立柏病院, 柏厚生総合病 院, おおたかの森病院, 慈恵医科大学附属柏病院, 名 戸ヶ谷病院, 流山市 : 東暮病院, 流山中央病院, 千葉 愛友会記念病院の 13 病院の体制となった。運用基準 としては, 原則として患者在所同一市内の二次救急当 番病院に搬送後GIB対象症例と診断された場合, GIB 当番病院に確認のうえ搬送することになっている．た だし救急隊員が消化管出血と判断した場合, 患者在所 と GIB当番病院が同一市内なら直接 $\mathrm{GIB}$ 当番病院に 確認のうえ搬送できる. また, 患者在所同一市内の二 次救急当番病院に搬送するよりも明らかに当該 (他市 の) GIB当番病院搬送が短時間と見込まれるときは, やはり直接 GIB当番病院に確認のうえ搬送できるこ とになっている.

\section{当院における活動状況}

当院は内視鏡室スタッフの協力の下, 日本消化器内 視鏡学会指導医 3 名, 専門医 1 名を含む内視鏡医 9 名 の体制でネットワーク開始時より今日まで活動してい る. 2010 年 3 月から 2012 年 2 月までの 24 力月間に当 院に搬送された $\mathrm{GIB}$ 症例は68例 (月平均 2.83 例), 性 別は男性 49件, 女性 19 件で年齢は 24 歳から 98 歳ま で平均65.8歳 (男性は24歳から 89 歳で平均 60.2 歳, 女性は 50 歳から 98 歳で平均 80.2 歳) であった。吐血 を主訴とした上部消化管出血は48例 (男性 33 例, 女 性 15例), 下血を主訴とした下部消化管出血は20例 （男性 16 例，女性 4 例）であった。このうち消炎鎮痛 剂常用 9 例, 抗凝固療法中 17 例で, 興味深いことに 認知症を含め統合失調症など精神疾患併存例が 13 例 であった．3時間以内に処置を含む緊急内視鏡検査を 行った症例は 21 例で (表-1), 残念ながら 3 名の方 (1) 
表-1 患者背景

\begin{tabular}{llccc}
\hline & & 吐血 $\rightarrow \mathrm{GIF}$ & 下血 $\rightarrow \mathrm{CF}$ & 計 \\
\hline 内視鏡検查 & 3h 以内 & 21 & 0 & 21 \\
& 24h 以内 & 13 & 3 & 16 \\
& 24h 以降 & 9 & 10 & 19 \\
& 未実施 & 5 & 7 & 12 \\
\hline 計 & 48 & 20 & 68 \\
\hline
\end{tabular}

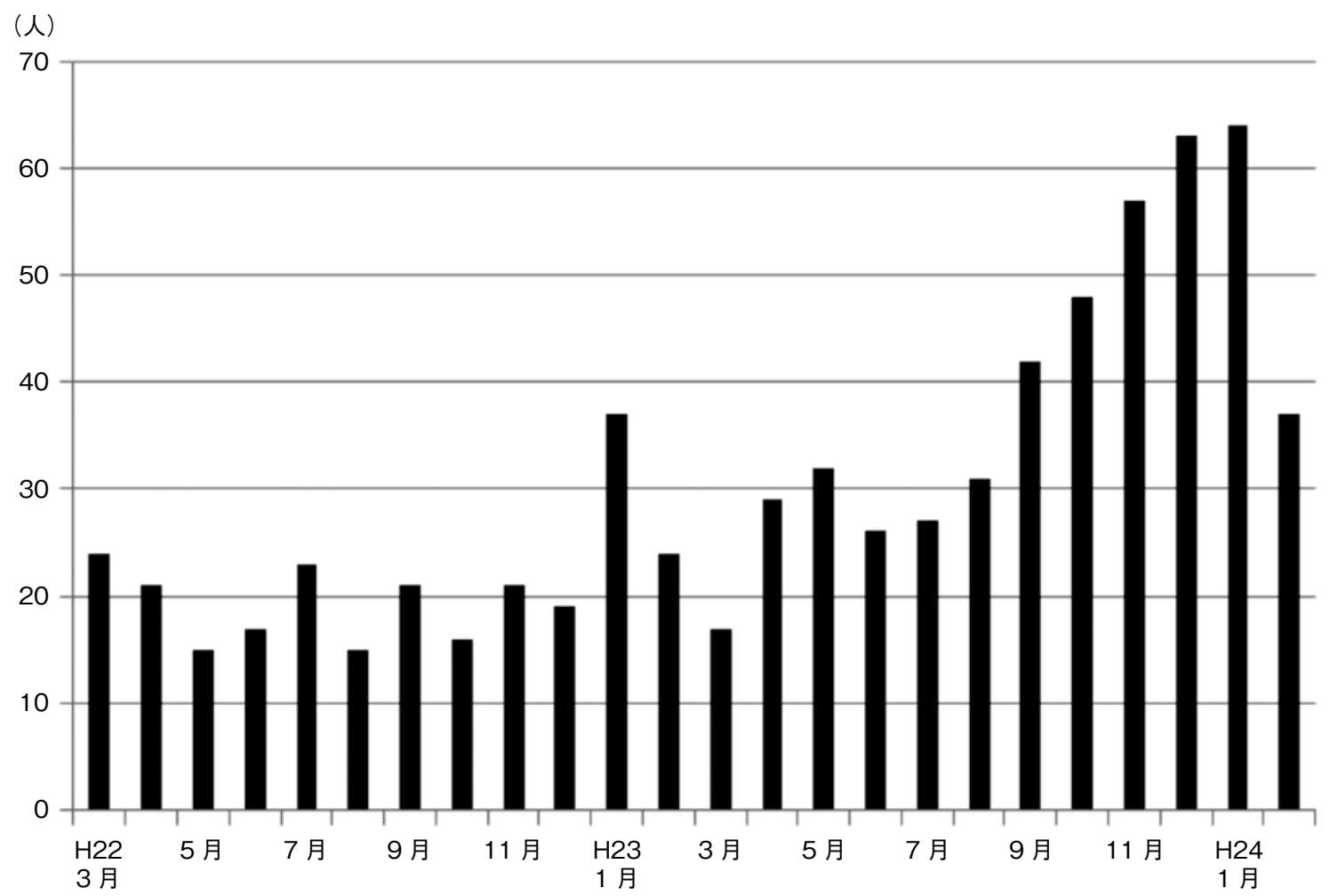

図-1ＧIB ネットワーク搬送実績

$84 \mathrm{y} ， \mathrm{~F}$ ，上部，搬送時ショック状態，(2) $96 \mathrm{y} ， \mathrm{~F}$, 上 部, 搬送時 $\mathrm{WBC} 28,700 / \mu l$, (3) $86 \mathrm{y}, \mathrm{M}$ ，下部，搬 送時PLT $\left.3.3 \times 10^{3} / \mu l\right)$ をショック・呼吸状態悪化の ため救命できず搬送後 24 時間以内に失った，それ以 外の症例は搬送時比較的状態が安定しており保存的加 療開始後待機的内視鏡検查を行っているが, 内視鏡検 査未実施の症例も 12 例あった。緊急手術例はなく, 待機手術を 3 例 (1) $60 \mathrm{y}, \mathrm{M}$, 上行結腸悡室出血, 入 院後 3 日目に腹腔鏡下右結腸切除術, (2) $44 \mathrm{y}, \mathrm{M}$, 出 血性胃潰瘍・幽門狭窄，入院後 26 日目に幽門側胃切 除術, (3) $50 \mathrm{y}, \mathrm{M}$ ，食道裂孔ヘルニアに伴う胃軸捻転， 入院後 13 日目に腹腔鏡下食道裂孔ヘルニア修復術）に 行った。 入院期間は0〜61日（平均 11.3 日）であった. 当院への所属別搬送救急隊の内訳は, 松戸救急 41 例, 柏救急 9 例, 流山救急 1 例, 近隣地域救急 17 例であっ た.

\section{GIB ネットワークの問題点}

当院では以下のような事例を経験した。てんかん発 作で転倒し口腔内挫創による出血でGIB 搬送，気管 支拡張症による喀血でGIB搬送，当日の痔核手術後 出血で施術病院を受診したが当直医が止血できずGIB 搬送など適応に疑問のあるものや，三郷市 (埼玉県) から気がついたら遠い柏市のGIB病院に搬送されて いたり, 長距離搬送後 GIB病院到着時にはショック 状態で死亡など運用リスクと考えられるものもあっ た.これらのことから GIBネットワーク運用上以下 のような問題点が浮き彫りとなってきた. (1)ネット ワーク自体の運営コストがかかる. (2)参加病院での採 算性. 補助金はなく各病院の運営努力による. (3)長距 離搬送のリスク。患者の安全確保と患者在所搬送病院 間の利便性は重要である. (4)三市以外の近隣地域から の要請と受け入れ，(5)消化管出血以外の症例もみられ る. 


\section{考察}

GIB ネットワーク稼働から 2 年が経過し GIB搬送症 例は徐々に増加してきている（図-1）。当院への所属 別搬送救急隊の内訳で松戸市からが $60.3 \%$ を占め, ネットワーク設立時からの松戸市の受け血的な傾向が あるように思われた。 また $25 \%$ がネットワーク以外 の近隣地域からの搬送であった。これらのことから ネットワーク運用上の問題点も次第に明らかになって きた．特に長距離搬送のリスクを考え患者の安全を確 保することは非常に重要であり, 効果的にネットワー クを維持するためにも, GIB当番病院と二次救急当番 病院, 救急隊の良好なコミュニケーションが重要であ ると思われた，GIB対象症例の増加要因として，ネッ トワーク機能が充実してきた反面，三市以外の近隣地 域でのネットワーク認知度上昇に伴う搬送数増加や, システム稼働から 2 年経過し本来のネットワークの意 義・運用基準の認識の低下などの可能性も考えられ
た，GIB 適応外と思われるような，吐・下血の現病歴 が曖昧な症例などGIB 適応の判断は慎重に行われる べきと思われた。 また三市以外の周辺地域からの要望 には患者本位に柔軟な対応を行い周辺地域にも貢献し ている反面，今後周辺地域からの搬送依頼が増加する ことも考えられ，ネットワーク運用上検討を要すると ともに近隣地域でのさらなる取り組みにも期待した い.またネットワーク 13 病院における症例分析を同 一スケールで行い，今後の運用のさらなる充実を図る ことも必要であると考える.

$$
\text { まと め }
$$

当院における松戸・柏・流山三市 GIB (消化管出血) ネットワーク活動状況とネットワークの今後の問題点 について報告した.

本論の内容は第98回日本消化器病学会総会 (東京) で発表した。

\title{
REPORT ON OUR ACTIVITIES FOR GIB NETWORK OF MATSUDO, KASHIWA, AND NAGAREYAMA GITIES
}

\author{
NAOKI ASAKAge*1), TATSUshI SUWA*1), SUnAo AKIYAMA*2) \\ *1) Department of Surgery, Kashiwakousei General hospital, Chiba, Japan, *2) Department of Medicine, \\ KashiWAKOUseI General HOSPITAL, ChIBA, JAPAN
}

\begin{abstract}
Three cities in Chiba Prefecture, Japan (Matsudo, Kashiwa, and Nagareyama) have been operating a nighttime and weekend emergency treatment system called the GIB (for gastrointestinal bleeding) Network in order to provide emergency medical services including endoscopic hemostatic treatment for acute hematemesis or melena patients since March 2010. This is a report on our hospital's activities related to the network from March 2010 through February 2012. Our experience has shown that smooth communication among hospitals on GIB duty, hospitals designated as secondary emergency service institutions, and ambulance squads is vitally important in order to maintain efficient network operations.
\end{abstract}

Keywords : GIB (gastro intestinal bleeding), endoscopic treatment, emergency treatment, nighttime and weekend emergency treatment system 